\title{
A SOCIAL INNOVATION IMPACT ASSESSMENT MATRIX
}
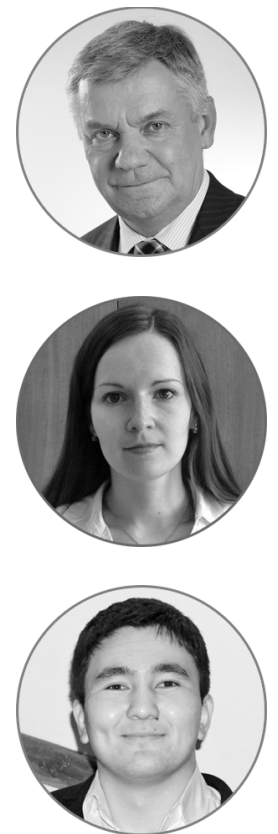

\section{Article history:}

Received 15 May 2017

Received in revised form 1 June 2017

Accepted 26 June 2017

Translated 16 October 2017

Available online 14 December 2017

JEL classification: L31, 035

Keywords: social innovation, performance matrix, effective

development, institutional environment

\section{Evgenii V. POPOV}

Institute of Economics of Ural Branch of Russian Academy of Sciences, Yekaterinburg, Russian Federation

epopov@mail.ru

\section{Anna Yu. VERETENNIKOVA}

Institute of Economics of Ural Branch of Russian Academy of Sciences, Yekaterinburg, Russian Federation

vay_uiec@mail.ru

\section{Corresponding author}

\section{Zhoomart K. OMONOV}

Ural Federal University named after the First President of Russia B.N. Yeltsin, Yekaterinburg, Russian Federation jomaomon@gmail.com

The editor-in-charge of this article was Irina M. Vechkanova

Authorized translation by Irina M. Vechkanova

\section{Introduction}

Being inherent in the Russian economy and embodied in both economic and political crises,

${ }^{\dagger}$ For the source article, please refer to: Попов Е.В., Веретенникова А.Ю., Омонов Ж.К. Матрица оценки результативности социальных инноваций. Региональная экономика: теория и практика. 2017. T. 15. Вып. 9. С. 1752-1772. URL: https://doi.org/10.24891/re.15.9.1752 unstable economic processes made the public sector and society morph significantly. This phenomenon stems from an outdated economic model used to create private and public benefits, thus pushing a search for alternative solutions to social problems. In this respect, social innovations grow even more important, since they are an effective tool to improve 
societal wellbeing and quality of living. They rapidly gain more and more traction among scholars and practitioners.

The study is very opportune as Europe sees social innovation researches growing in numbers, such as CRESSI, SIMPACT, ITSOIN, SIDrive, TRANSIT, ImPRovE, ThirdSectorImpact, BENISI, SOCIALPOLIS,TEPSIE, SINGOCOM, KATARSIS, WILCO, PASHMINA. Another evidence can be illustrated with:

- Social Innovation Residency Conference in Canada;

- Social Innovation Summit in San Francisco;

- Social Innovation Forum in Turkey;

- regular thematic TACSI meetings in Australia;

- Young Foundation in London;

- White House Office for Social Innovation and Civic Participation, Washington;

- Center for Social Entrepreneurship and Social Innovation Studies (Higher School of Economics, Russia), etc.

This attention to social innovations is rather expectable. Social innovations are designated to address current social issues using more effective methods.

Analyzing global trends, we see national governments making considerable investment in social innovation development. However, the outcome often dissatisfies expectations. There is a lack of a theoretical and methodological framework which would respect institutional conditions for social innovation development, while implementing the State policy, reforms, and updating socio-economic processes. Furthermore, the balance of social and economic goals also becomes a focal point. It not only makes social and innovative projects efficient, but also draws attention of businesses and public to this phenomenon.

Therefore, this research aims to articulate our own matrix for evaluating the efficacy of social innovations. We intend to achieve this goal by providing our own definition of social innovations, analyzing development approaches, describing the specifics of social innovation development, and evaluating possible areas of their development.

\section{The Concept of Social Innovation}

Notwithstanding the relevance of social innovations, their theoretical framework is originating. Social innovation constitutes an effective vehicle to reach higher societal wellbeing [1]. The principal and most renowned examples of social innovations feature Wikipedia, Open University, Coursera, KhanAcademy, etc. Most of rather ordinary and habitual things and aspects were considered social innovations several decades ago. For example, Friedrich Fröbel's idea of pre-school education seemed innovative, being effectuated as the first kindergarten in 1837 [2].

However, scholarly literature fails to provide a generally accepted interpretation of social innovations, thus necessitating a more thorough investigation of the issue. Having analyzed definitions of social innovation, we pointed out three principal approaches.

Proponents of the first approach [2-5] construe social innovations as novelties intended to attain socially-important goals. The social content shall be ingrained not only in the ultimate result, but also in the process of the activity.

As part of the second approach, D. Chalmers [6], R. Heiscala [7], M. Minks [8], J. Phills, K. Deiglmeier, D. Miller [9] and the Center for Social Innovation at the Stanford University view social innovations as novelties, which occur in the social environment. The approach emphasizes procedural, institutional and organizational changes, thus allowing to apply the framework of the institutional theory for respective researches.

Proponents of the third approach, such as B. Amable [10], C. Battistella, F. Nonino [11], P. Koch, J. Hauknes [12], Sang Lee, Taewon Hwang, Donghyun Choi [13], use the concept innovation in the social sector. It likens social innovations to social benefits. As part of this research, we suggest interpreting social innovation as new combinations of resources in social production that change the institutional context and/or inducing a more effective solution to social problems. Social innovations, virtually and essentially, enhance the use of resources so as to address social problems primarily [14]. 


\section{Development Specifics of Social Innovation}

Whereas there is no common theoretical and methodological framework for social innovation studies, many views are expressed concerning their role and development distinctions. On the one hand, due to nonexistent economic incentives, social innovations are often perceived as an atypical market phenomenon or consequence of one of the market failures [15]. On the other hand, social innovation development is an exclusive authority of the State. Social innovations, hence, result from civil society's activities and fill in a critical gap between the market and the State [16]. In this case, it becomes especially important to consider whether the institutional environment is effective and whether relevant mechanisms exist to encourage socio-innovative activities of the society.

As held in the theory of the Bottom of the Pyramid, social innovation becomes one of the method to mobilize the poor or marginalized layers of the society. Social innovations provide these social groups with the opportunity of addressing social problems, including public benefits $[17,18]$. In other words, the poor population is offered an opportunity to create conditions for sustainable social innovations.

According to the Young Foundation [2] actively promoting social innovation worldwide, the specifics of social innovation creation and development influences the way innovative groups and sponsors supporting socio-innovative initiatives interact. The sponsorship implies the funding, advice and creation of necessary conditions. We emphasize it is important to arrange communication and cooperation institutions for innovators and sponsors, being a crucial driver of social innovation development.

Social innovation development especially depends on the level of social capital and informal institutions within the respective territory. As L. Polishchuk and R. Menyashev note [19], social capital comes out if citizens can unite their efforts for solving public issues. It may substitute public institutions or supplement them. The level of social capital development becomes even more important in emerging economies, where civic cooperation may partially make up gaps in the production of common goods. The construction of schools and hospitals supported by local communities is a good illustration of that [20]. Thus, social capital is indispensable to social innovation the society promotes.

Underlying the development of social innovations undertaken by citizens, informal institutions design collective endeavors. The researchers, such as A. Dorward, J. Kydd, J. Morrison and C. Poulton, state that each step of economic development entails respective costs and failures on the part of the public and social organizations. In this respect, information institutions play an important role in tackling information asymmetry, solving social problems and providing the society with common goods.

Following the alternative approach to social innovation studies, it is necessary to analyze factors that influence the socio-innovative process. For example, D. Chalmers [6] attempted to sort out the factors into three categories, i.e. protectionism and attitude to risk, distinctive nature of human assets, and network and cooperation (Table 1).

The first group of factors concerns the resistance to changes arising from social innovation. The resistance may occur in response to a social innovation or in the process of using it. Governmental officials in charge of the public sector development and immediate producers of common goods are often not interested in changes that may influence not only their habitual behavior but also affect the volume of resources they dispose of.

The public often tends to be cautious about changes, since people accept and perceive any social system as values, code of conduct and habits. The longer the system operates and provides people with the alleged security and prosperity, the more its principles strike roots in the public mind [21,22].

The required distinctive nature of human assets underlies the second group of factors. Social problems are a complex and multifaceted phenomenon, for which there is no versatile mechanism or formula. It requires specific knowledge, additional efforts, high creativity of agents and, subsequently, involvement of the society. For example, a variety of social issues from urban waste recycling to municipal wind farms - engendered the environmental movement 
(environmentalism), which pursues the environmental protection. The environmental movement was propelled by multiple and various exepertise and ideas of its advocates involved in the process. The environmental movement and its idea dates back to the time of forest and landscape protection movements in the 19th century and initiatives for biological diversity conservation, etc. Moreover, certain governmental officials promoted the policy for reducing wastes of large companies, thus securing the indemnification for the affected parties. Direct-action movements originated that time (Greenpeace and other green parties worldwide).

The third group of factors refers to network and cooperation issues. They include certain gaps in setting up effective communication ties throughout the stages of the socio-innovative process. We mean non-existent effective rules and principles for economic agents to cooperate and create common goods. Drawing upon social innovation studies, the researchers F. Lettice, M. Parekh [23] mentioned that such gaps had a negative impact on the psychological attitude of social innovators, impede the fund raising process and aid, whereas strong networks help innovators find their identity and establish mutually beneficial relationships with all stakeholders [6].

As D.R. Young, J.D. Lecy note [24], entities creating social values in the market environment should effectively combine the social mission and profitmaking activities so as to ensure their sustainable development. We point out such forms of social innovation as social entrepreneurship, social enterprises, social responsibility of businesses, social cooperation, hybrid entities and non-profit organizations (Fig. 1).

Social business is oriented at strategic achievements, where the social mission facilitates the improvement of social relationships and effective cooperation with the State.

Social entrepreneurship strives to balance the creation of social value and earnings.

Non-profit entities are free from profit-making objectives, however, they may earn profit to remain a going concern. The category includes such traditional entities as non-profit theaters, hospitals, schools, and providers of social services, etc. Please find below the main distinctions of such entities:

- costs are covered with revenue;

- profit is not a guiding principle;

- other sources of finance are used unless revenue covers costs entirely (State subsidies, financial aid from foundations, etc.).

From social perspectives, public private partnership (PPP) implies the contractual interaction of profit-making, non-profit and governmental organizations in pursuit of socially important goals. Although each party has its owns goals and objectives, it is possible to trace the common socially-oriented mission and profit-making expectations. To develop this format, it is reasonable to rely upon proceedings by the 2014 Nobel Prize winner J. Tirole [25].

Hybrid entities constitute new forms and systems of contractual relationships among entities, which unite to implement long-term social projects, and use resources more effectively [26].

Social cooperation are associations of citizens focused to attain social benefits.

Social enterprises are a type of entities set up for social purposes, but governed by a profit-making strategy.

Hence, the social innovation development requires, on the one hand, methods for addressing social issues, and break-even performance, on the other hand.

Adhering to the above approaches, we suppose, social innovation evaluation criteria should be used from perspectives of private and social benefits that the producer and consumer of social innovations derive respectively.

Social benefits shall mean a certain payoff for the society or a social group. This may be a positive change in the social welfare. Social benefits have two important characteristics, i.e. quantitative and qualitative ones.

Quantitative characteristics shape the social scale and coverage of a social innovation. In the mean time, qualitative characteristics are usually gauged 
through expert assessments or industry-specific metrics.

Private benefits constitute possible payoffs for agents initiating social innovation:

- profit in case of social entrepreneurs;

- tax credits, better reputation, long-term increase in corporate value, etc. in case of socially-oriented businesses;

- possible professional promotion and advancement in case of governmental employees;

- amplified pool of voters in case of politicians;

- higher ratings, expanded activities in case of research and development institutions.

To account for private and public benefits, we devise a matrix for evaluating the efficacy of social innovation (Fig. 2).

In the first quadrant, social innovations do not generate any benefits for the society and individuals. This quadrant includes new social innovations launched in the market or unsuccessful ones.

The second quadrant reflects unprofitable social business, unsustainable social enterprises. The effective institutional environment shall be created and developed so that social innovations could be attributed to the high profitability quadrant.

The third quadrant concerns two cases:

- in the first case, social innovations do not generate substantial public payoff, but they are profitable for their producer;

- in the second case, social innovations are side-effects of profit-making entities.

The production of social innovations can be common for both cases as a secondary effect of corporate operations.

The forth quadrant is a perfect situation to achieve. Social innovations and their development in this quadrant depend on the socially-oriented institutional environment, which boosts the development and support of social innovations and creates conditions for them.

Merging all approaches, the leitmotif of social innovation development is the balance of profit-making activities and the social mission for all social innovation sources, other than authorities and volunteers. For purposes of practical studies into socio-innovative projects combining social and commercial benefits, we proceed with a practical analysis of social innovations in the Sverdlovsk Oblast.

\section{The Application of the Social Innovation Efficacy Assessment Matrix}

To analyze the applicability of the social innovation efficacy assessment matrix, we examine twenty social enterprises' activities in the Sverdlovsk Oblast within 2012 through 2017. The analyzable innovations were implemented in various organizational forms so that we could evaluate corporate performance and social efficiency (Fig. 2).

To review the given socio-innovative projects, we construct an adapted matrix for assessing the social innovation efficacy. Considering a diversity of incentives and benefits for participants of socio-innovative projects (both developers and consumers), it is necessary to choose indicators, which would allow to quantify commercial and social benefits. Being empirically assessed, project profitability was chosen as a descriptor of commercial benefits. We count the number of project consumers to understand social benefits. The rate of return is a convenient metric reflecting the profitability (unprofitability) and the project payback, while the number of social innovation consumers reflects the magnitude of social effect the proposed innovation has. In this case, the zero rate of return was considered as the threshold between high and low private profit. Private profit is deemed high if the rate of return is positive or zero, i.e. the project coveres its costs. Traits of social benefits are traced in each particular case.

Considering that social innovations are significantly different in the way they work, all the analyzable projects were divided into three groups:

- the first group includes small social innovations with the budget of RUB 100 thousand or lower;

- the second group includes medium social innovations with the budget ranging from RUB 100 thousand to 300 thousand; 
- the third group includes large social innovations with the budget exceeding RUB 300 thousand.

Having analyzed small social innovation, we found the inverse dependence between the profitability and an increase in the number of consumers (Fig. 3). The dependence is expressed with the following formula:

$$
R=-0,978 N+0,051\left(r^{2}=0,7908\right),
$$

where $R$ is the profitability metric;

$N$ is the number of consumers.

Having analyzed medium-scale innovations, we detected the inverse dependence between the profitability and an increase in the number of consumers too (Fig. 4):

$$
R=-0,376 N+0,144\left(r^{2}=0,7493\right) \text {. }
$$

Profitability of large social innovations is also inversely related to the number of consumers (Fig. 5) and expressed with the following formula:

$$
R=-0,221 N+0,258\left(r^{2}=0,705\right) \text {. }
$$

The analysis reveals the first distinction of the analyzable socio-innovative projects. That is the declining profitability trends against the increasing number of consumers. In particular, the profitability turns to be below zero for small social innovations with 52 consumers, 382 consumers for medium ones and 1,167 consumers for large ones.

The second distinction is the rapidity of a profitability decrease in case of the extended coverage. This is expressed with the coefficient preceding the $\mathrm{N}$-variable in regression equations. If the scale and coverage increase, the profitability of social innovation dips down in the first group of projects, which have the coefficient of -0.978 . The second group has the coefficient of -0.376 emphasizing the less drastic drop in the profitability. The third group has the coefficient of -0.22 , being the lowest drop in the profitability among all the groups. Drawing upon the results, we conclude that each 100 consumers of small social innovations make the profitability drop by 9.78 percent, while this indicator is 3.7 percent for medium ones and 2.2 percent for large ones.
Summing up the analysis outcome, we make the following conclusions.

1. Social innovation support institutions prove to be ineffective, thus affecting the profitability amid an increasing social effect.

2. Notwithstanding the substantial unprofitability, social innovations still generate social payoff, thus confirming high demand for them. It is evidence of the formation and development of social capital in the analyzable area.

3. We determine the issue of the growing scale of social innovators' activities. Assuming that the recoupment of social innovation is the critical basis for sustainable development, its decrease and concurrent growth in social benefits signify the existing barriers impeding the expansion of socio-innovative activities.

It is possible to provide various explanations concerning the way the increased number of consumers of social innovations affects their profitability. On the one hand, the profitability may decrease as social innovations are more oriented at poor and marginalized layers of the population, thus engendering the inverse effect due to the scale effect. On the other hand, it may stem from the infancy stage of social innovation from practical and theoretical perspectives. In both cases, it may be necessary to design a system of institutions in order to alter the trends we reveal.

\section{Designing Institutional Changes in Social Innovation}

Adhering to theoretical and methodological principles of institutional engineering and social innovation development, and data of the empirical study, we shall spotlight initiative development issues, issues of scaling and diffusion of social innovations $[6,27,21]$.

As socio-innovative activities in the Sverdlovsk Oblast, more often than not, result in losses, we conclude on a certain reluctance of undertaking social innovation projects. Moreover, it is accompanied with the following circumstances [6]:

- high risks arising from the non-transparency of social institutions; 
- lack of knowledge and expertise in social innovation;

- insufficient support from the State;

- resistance of the population and State to innovation.

The issues of social innovation scaling inflict difficulties in raising the number of consumers. In this respect, the aspects below increase the scale of social innovation:

- chaotic and poor dissemination of information;

- imperfect mechanisms for financial support;

- lack of social innovation support institutions;

- insufficient confidence level in the region.

The above factors and respective solutions are given in Table 2.

As mentioned before, the confidence level plays an important role in finding a collective solution to social issues. As the researcher M. Fafchamps [20] mentioned, the confidence level can be raised by two options, i.e. by setting up robust social institutions or developing social capital. The efficient-formalinstitutional environment can be created in the long run only. That is why social capital development turns out to be the best tool in the short run. Furthermore, setting up unions, associations of social innovators, development and implementation of effective models for public involvement in social processes are of special significance.

Most models for public need satisfaction become outdated and ineffective in the current circumstances. However, the overwhelming majority of population and authorities resist to changes, since they always bring uncertainty. As V.L. Tambovtsev believes [28], direct and indirect stimulation methods are applicable in this case.

Direct stimulation methods shall include advocating that is, in fact, active and streamlined activity for explaining the substance and advantages of social innovation, substantiating and stimulating the public involvement into the activity. Unlike simple endorsements and promotion, advocating represents a specially trained team of professionals who are skilled in maintaining understandable and effective communication and public involvement.
Indirect stimulation methods represent a regulatory link between private benefits and social payoff.

Chaotic and insufficient dissemination of information is a particular case of its asymmetry impeding the social innovation development (the adverse effect of the issue is partially decreased). Furthermore, information support institutions for social innovations will also have a positive impact.

Social innovation development is difficult to imagine without effective financing mechanisms. For this purpose, foundations and special lending conditions shall be created for social innovation. Developing PPP institutions is of paramount importance. For instance, it is necessary to amend the federal law on concession agreements since the existing procedure restricts private investors' rights, since terms of contracts with authorized governmental bodies are difficult to amend. Moreover, investors can be lured into the area by ensuring the transparency of the social sector, introducing innovator activity insurance programs and creating powerful incentives for social entrepreneurship and social business to evolve.

\section{Conclusion}

Intended for the development of our own social innovation efficacy assessment matrix, this research leads to the following conclusions.

First, it is necessary to substantiate the interpretation of social innovation as new combinations of resources in social production that change the institutional context and/or fostering a more effective solution to social production issues.

Second, the social innovation efficacy assessment matrix should be devised, implying public and private benefits and allowing to systematize possible forms of social innovation by given criteria.

Third, it is reasonable to identify trends in the development of small, medium-sized and large social innovations at the regional level and demonstrate the way they decrease if the project scale grows. This phenomenon may result from ineffective conditions for the social innovation development in the analyzable region.

Forth, it is advisable to outline key paths for the institutional development of social innovations. 
From theoretical perspectives, this research amplifies the existing principles of the innovation theory in relation to the social sector and the social innovation concept. From practical perspectives, the findings are significant and meaningful since they can be used to improve regional development programs and outline entrepreneurship activation measures in the analyzable regions and social sector, in particular.

\section{Table 1}

Factors for the social innovation development by D. Chalmers

\begin{tabular}{ll}
\hline Group & Factors \\
\hline Protectionism and risk attitude & Confidence level \\
\cline { 2 - 2 } & Public resistance to innovation \\
\cline { 2 - 2 } & Risk assessment \\
\cline { 2 - 2 } & Dissemination of information on social innovation \\
\hline Reproduction of the best socio-innovative practices \\
\hline Netwics of human assets & Rowledge and skills \\
\cline { 2 - 2 } & Road map \\
\hline Institutions for public private and municipal private partnership \\
\hline
\end{tabular}

Source: [6]

Table 2

Factors for the social innovation development

\begin{tabular}{ll}
\hline Social innovation development factors & Development area \\
\hline Confidence level & Development of robust formal institutions, social capital \\
\hline Resistance of the public and authorities to innovation & $\begin{array}{l}\text { Designing institutions for communication and involvement the public into } \\
\text { socio-innovative activities }\end{array}$ \\
\hline Dissemination of information on social innovation & $\begin{array}{l}\text { Setting up institutions for information dissemination. } \\
\text { Creating the platform for social entrepreneurs }\end{array}$ \\
\hline State support for social innovation & $\begin{array}{l}\text { Amending the law on concession agreements. } \\
\text { Outlining PPP programs for social entrepreneurs purposefully. } \\
\text { Supporting investment projects in the social sector (affordable loans, } \\
\text { reimbursement of expenses, etc.) }\end{array}$ \\
\hline Investment attractiveness of the private sector & $\begin{array}{l}\text { Ensuring the transparency of social activities. } \\
\text { Implementing programs for insurance of social innovators }\end{array}$ \\
\hline Accessibility of knowledge and skills needed for layout of the institutional & $\begin{array}{l}\text { Development of social innovation support institutions, introduction of } \\
\text { innovators' road map }\end{array}$ \\
\hline
\end{tabular}

Source:Authoring 


\section{Figure 1}

The forms of social innovation organizations

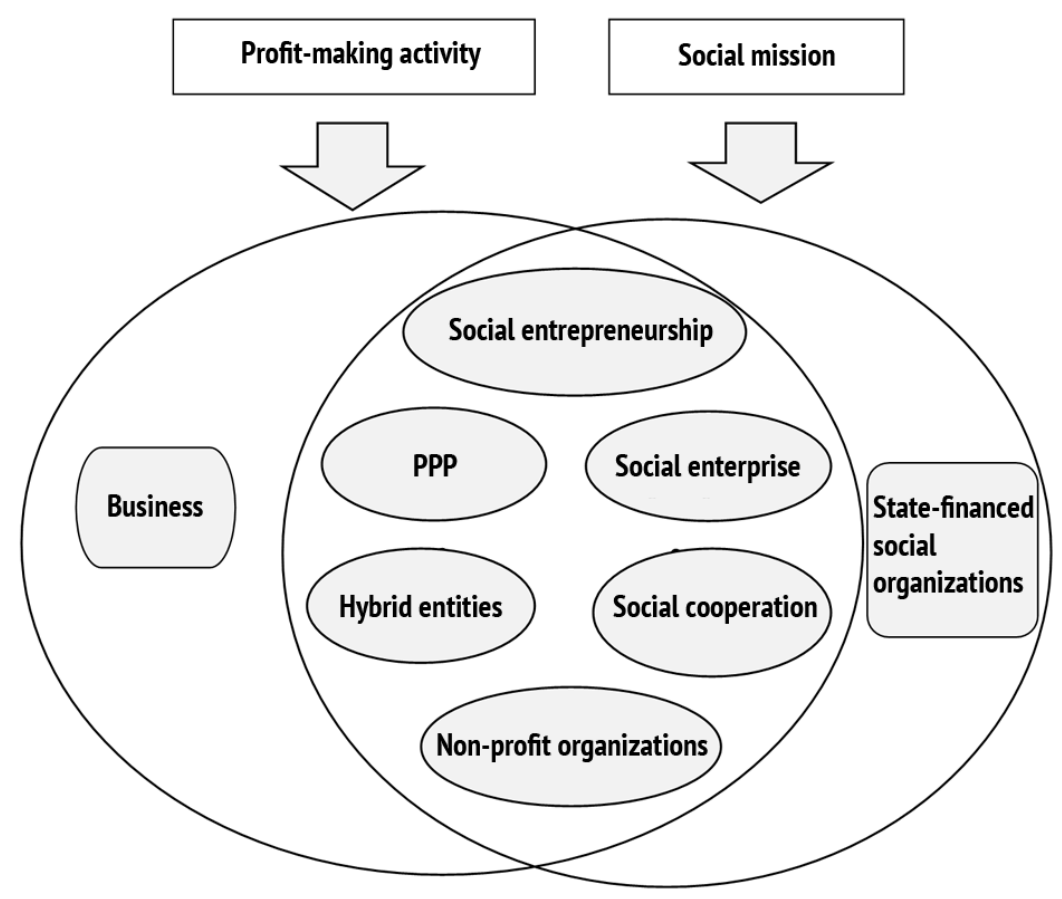

Source:Authoring 
Figure 2

Social Innovation Impact Assessment Matrix

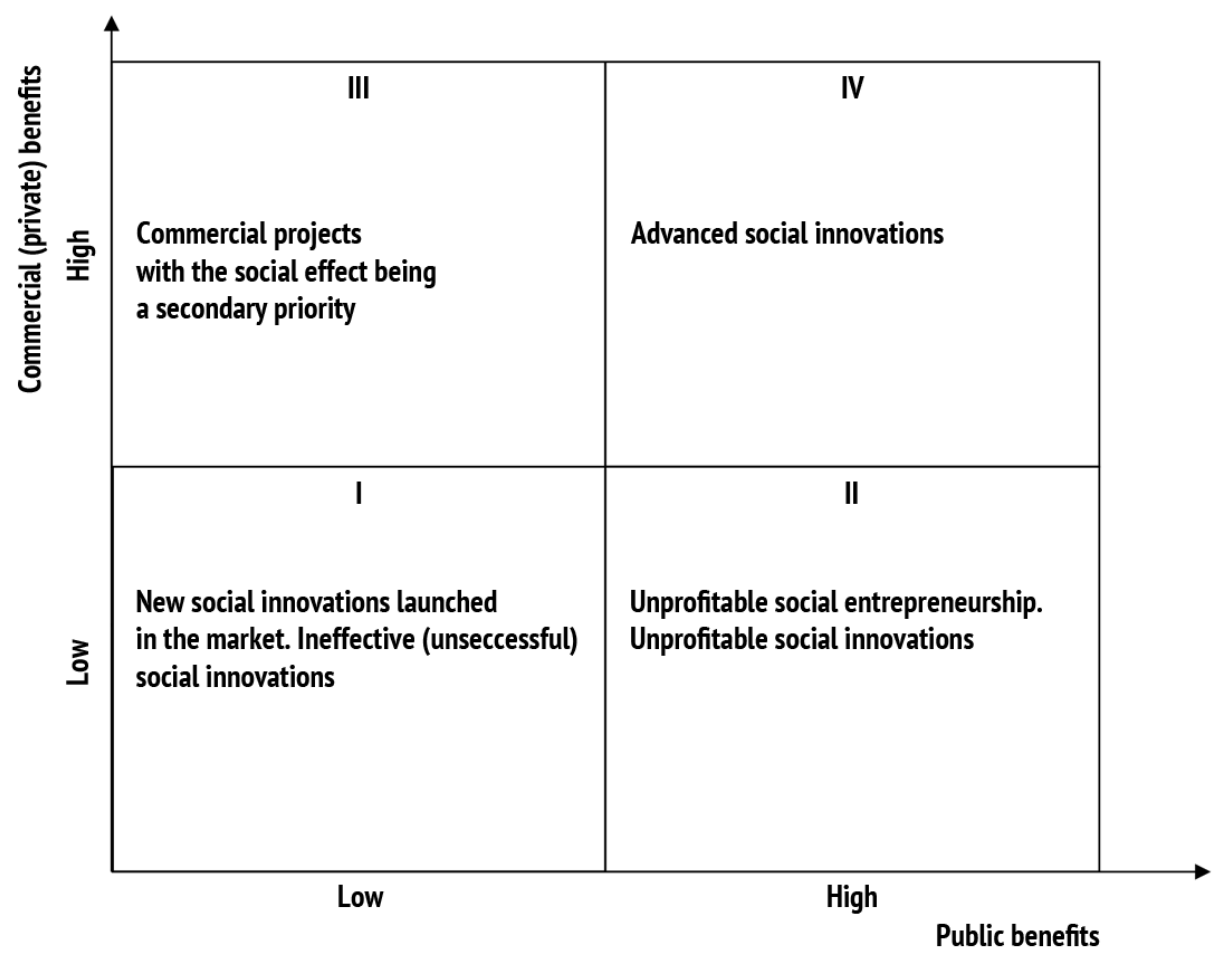

Source:Authoring

\section{Figure 3}

The dependence of profitability on smaller social innovation consumers

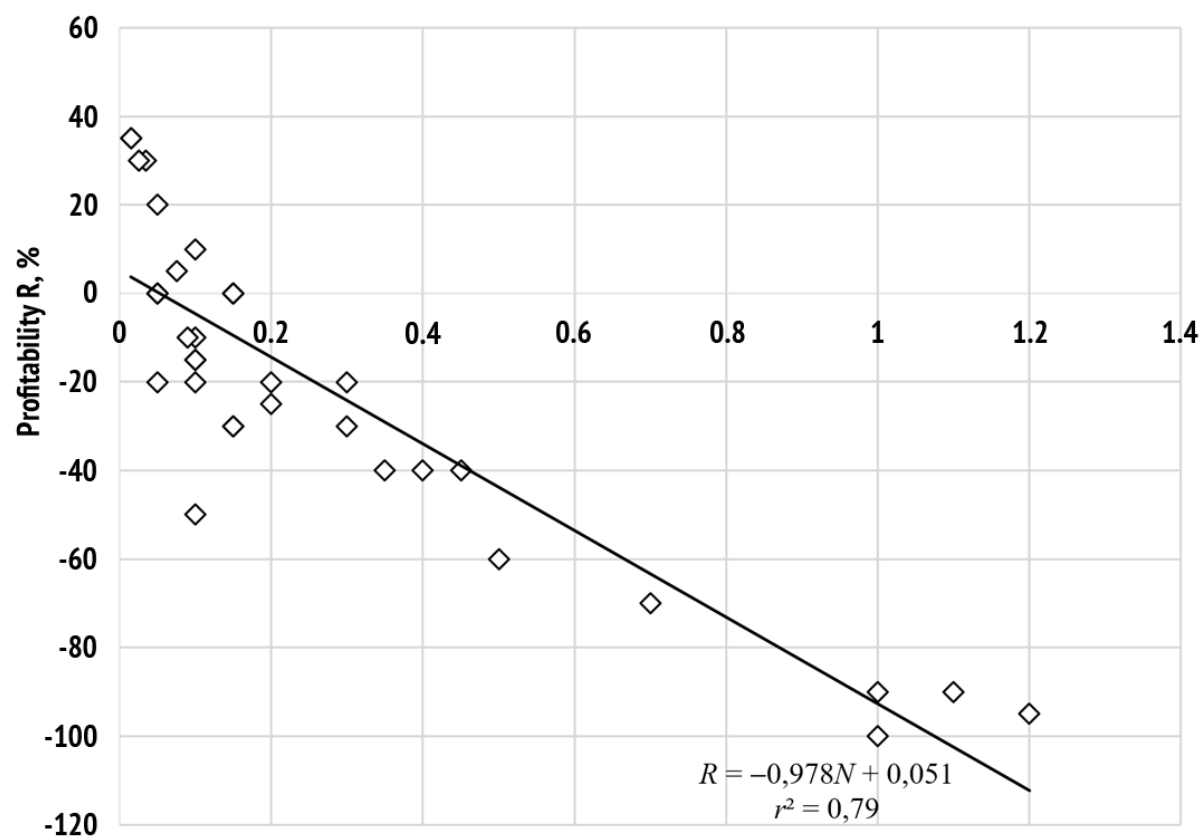

Consumers N, thousand people

Source. Authoring

Please cite this article as: Popov E.V., Veretennikova A.Yu., Omonov Zh.K. A Social Innovation Impact Assessment Matrix. Digest Finance, 2017, vol. 22, iss. 4, pp. 365-378. https://doi.org/10.24891/df.22.4.365 


\section{Figure 4}

The dependence of profitability on medium-sized social innovation consumers

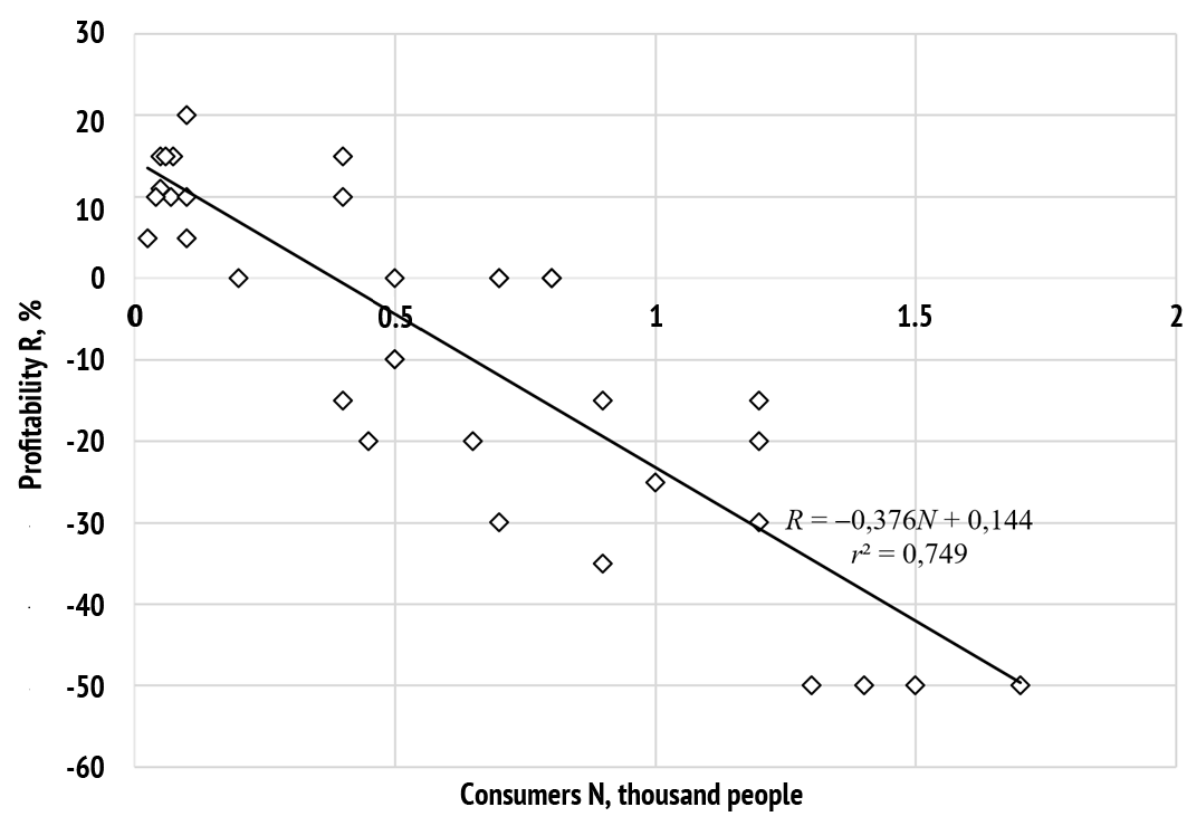

Source. Authoring

\section{Figure 5}

The dependence of profitability on major social innovation consumers

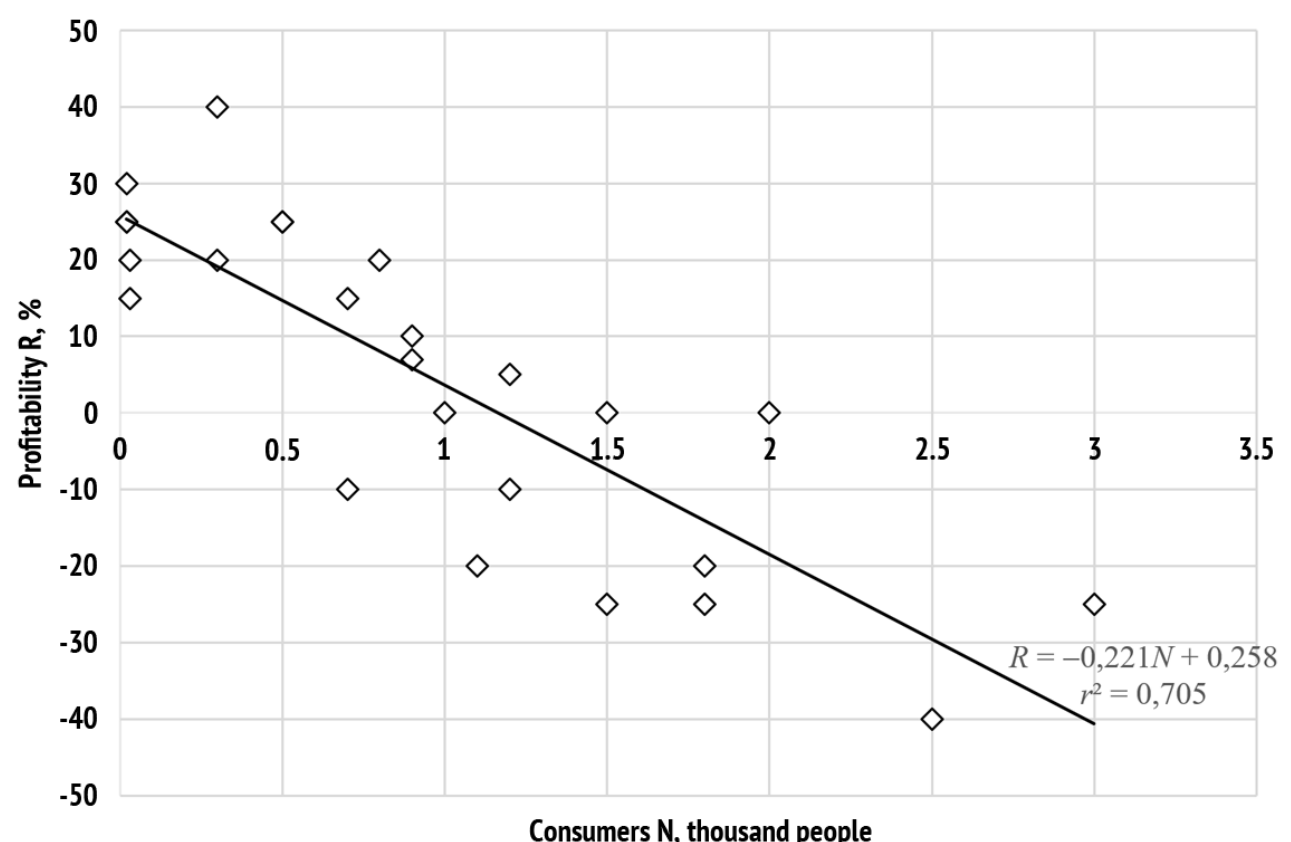

Source. Authoring 


\section{Acknowledgments}

The article has been prepared in accordance with the Research Plan of the Institute of Economics of the Ural Branch of the Russian Academy of Sciences, Federal Agency of Scientific Organizations Registration No. 0404-2015-0010.

\section{References}

1. Moore M.-L., Westley F.R. Public Sector Policy and Strategies for Facilitating Social Innovation. Horizons: Innovative Communities, Agents of Change, 2011, vol. 11, iss. 1, pp. 1-11.

URL: http://www.sosyalinovasyonmerkezi.com.tr/yayin/1020110007.pdf

2. Murray R., Caulier-Grice J., Mulgan G. The Open Book of Social Innovation. The Young Foundation, 2010, 224 p. URL: https://youngfoundation.org/wp-content/uploads/2012/10/The-Open-Book-of-SocialInnovationg.pdf

3. Moulaert F., MacCallum D., Mehmood D., Hamdouch A. (Eds). General Introduction: The Return of Social Innovation as a Scientific Concept and a Social Practice. The International Handbook on Social Innovation: Collective Action, Social Learning and Transdisciplinary Research. 2013, pp. 1-6. URL: https://www.elgaronline.com/view/9781849809986.00008.xml doi: http://dx.doi.org/10.4337/9781849809993.00008

4. Nicholls A., Ziegler R. An Extended Social Grid Model for the Study of Marginalization Processes and Social Innovation. CRESSI Working Papers, 2014, no. 2/2015, pp. 1-13.

URL: http://www.sbs.ox.ac.uk/sites/default/files/researchprojects/CRESSI/docs/CRESSI_Working_Paper_2_D1.1_Chp2_18Nov2014.pdf

5. Pol E., Ville S. Social innovation: Buzz Word or Enduring Term? The Journal of Socio-Economics, 2009, vol. 38, iss. 6, pp. 878-885. URL: http://doi.org/10.1016/j.socec.2009.02.011

6. Chalmers D. Social Innovation: An Exploration of the Barriers Faced by Innovating Organizations in the Social Economy. Local Economy, 2012, vol. 28, iss. 1, pp. 17-34.

URL: https://doi.org/10.1177/0269094212463677

7. Heiscala R. Social Innovations: Structural and Power Perspectives. In: Social Innovations, Institutional Change and Economic Performance. Edward Elgar Publishing, 2007, pp. 52-79.

8. Minks M. Social Innovation : New Solutions to Social Problems. Georgetown University Washington, D.C., April 11, 2011, 80 p.

URL: https://repository.library.georgetown.edu/bitstream/handle/10822/553359/minksMichaelLee.pdf? sequence=1\&isAllowed $=y$

9. Phills J., Deiglmeier K., Miller D. Rediscovering Social Innovation. Stanford Social Innovation Review, 2008, no. 6, pp. 33-43.

URL: https://ssir.org/images/articles/2008FA_feature_phills_deiglmeier_miller.pdf

10. Amable B. Institutional Complementarity and Diversity of Social Systems of Innovation and Production. Discussion Paper FS I 99-309, Wissenschaftszentrum Berlin für Sozialforschung, 1999, 36 p. URL: http://www.ssoar.info/ssoar/bitstream/handle/document/12915/ssoar-1999-amableinstitutional_complementarity_and_diversity_of.pdf?sequence=1 
11. Battistella C., Nonino F. Open Innovation Web-Based Platforms: The Impact of Different Forms of Motivation on Collaboration. Innovation: Management, Policy \& Practice, 2012, vol. 14, iss. 4, pp. 557-575. URL: https://doi.org/10.5172/impp.2012.14.4.557

12. Koch P., Hauknes J. On Innovation in the Public Sector. NIFU STEP, Oslo, 2005, 102 p. URL: https://ep.bib.mdh.se/login?url=http://search.ebscohost.com/login.aspx? direct=true\&db=edsref\&AN=IPSSPR.KOCH.NIFUSTEP.BJJF\&site=eds-live

13. Sang M., Hwang T., Choi D. Open Innovation in the Public Sector of Leading Countries. Management Decision, 2012, 22 p.

URL: https://www.researchgate.net/publication/235260881_Open_innovation_in_the_public_sector_of_lea ding_countries doi: 10.1108/00251741211194921

14. Popov E., Stoffers J., Omonov Z., Veretennikova A. Analysis of Civic Initiatives: Multiparameter Classification of Social Innovations. American Journal of Applied Science, 2016, vol. 13, iss. 11, pp. 11361148. URL: https://doi.org/10.3844/ajassp.2016.1136.1148

15. Sachs J.D. The End of Poverty: Economic Possibilities for Our Time. New York, The Penguin Press, 2005, $448 \mathrm{p}$.

16. Boettke P.J., Rathbone A. Civil Society, Social Entrepreneurship, and Economic Calculation: Towards a Political Economy of the Philanthropic Enterprise. In: Working Paper 8, The Philanthropic Enterprise, 2002, 26 p.

URL: http://www.conversationsonphilanthropy.org/wp-content/uploads/boettkerathbone-1.pdf

17. Prahalad C.K. The Fortune at the Bottom of the Pyramid: Eradicating Poverty through Profits. Revised Edition. Wharton School Publishing, 2004, 423 p.

18. Simanis E., Hart S. The Base of the Pyramid Protocol: Toward Next Generation BoP Strategy. Center for Sustainable Global Enterprise, Johnson School of Management Cornell University, Ithaca, 2008, 57 p. URL: https://www.johnson.cornell.edu/portals/32/sge/docs/BoP_Protocol_2nd_ed.pdf

19. Menyashev R., Polishchuk L. Does Social Capital Have Economic Payoff in Russia? Moscow, HSE Publ., 2011, 44 p. URL: https://isc.hse.ru/data/2011/03/31/1211874471/WP10_2011_01f.pdf

20. Fafchamps M. Development and Social Capital. Journal of Development Studies, 2006, vol. 42, iss. 7, pp. 1180-1198. URL: https://doi.org/10.1080/00220380600884126

21. Dorward A., Kydd J., Morrison J., Poulton C. Institutions, Markets and Economic Co-ordination: Linking Development Policy to Theory and Praxis. Development and Change, 2003, vol. 36, iss. 1, pp. 1-25.

22. Mulgan G. The Process of Social Innovation. Innovations: Technology, Governance, Globalization, 2006, vol. 1, iss. 2, pp. 145-162.

URL: http://www.mitpressjournals.org/doi/abs/10.1162/itgg.2006.1.2.14 doi: 10.1162/itgg.2006.1.2.145

23. Lettice F., Parekh M. The Social Innovation Process: Themes, Challenges and Implications for Practice. International Journal of Technology Management, 2010, vol. 51, iss. 1, pp. 139-158.

URL: https://doi.org/10.1504/IJTM.2010.033133

24. Young D.R., Lecy J.D. Defining the Universe of Social Enterprise: Competing Metaphors. Voluntas, 2014, vol. 25, iss. 5, pp. 1307-1332. URL: https://doi.org/10.1007/s11266-013-9396-z 
25. Tirole J. Market Power and Regulation. Economic Sciences Prize Committee of the Royal Swedish Academy of Sciences, 2014, 54 p. URL: http://www.ecgi.org/documents/sciback_ek_en_14.pdf

26. Menard C. The Economics of Hybrid Organizations. Journal of Institutional and Theoretical Economics, 2004, vol. 160, pp. 345-376. URL: http://www.dse.univr.it/documenti/Occorrenzalns/matdid/matdid425733.pdf

27. Cressey P., Totterdill P., Exton R., Terstriep J. Stimulating, Resourcing and Sustaining Social Innovation: Towards a New Mode of Public Policy Production and Implementation. SIMPACT Working Paper Series, 2015, vol. 3.

28. Tambovtsev V.L. [The State as Initiator of Development of Civil Society]. Obshchestvennye nauki $i$ sovremennost' = Social Sciences and Contemporary World, 2007, no. 2, pp. 69-77. URL: http://opuo.ru/wpcontent/uploads/drupal/nko_doc/gosudarstvo_kak_iniciator_razvitiya_go.pdf (In Russ.)

\section{Conflict-of-interest notification}

We, the authors of this article, bindingly and explicitly declare of the partial and total lack of actual or potential conflict of interest with any other third party whatsoever, which may arise as a result of the publication of this article. This statement relates to the study, data collection and interpretation, writing and preparation of the article, and the decision to submit the manuscript for publication. 